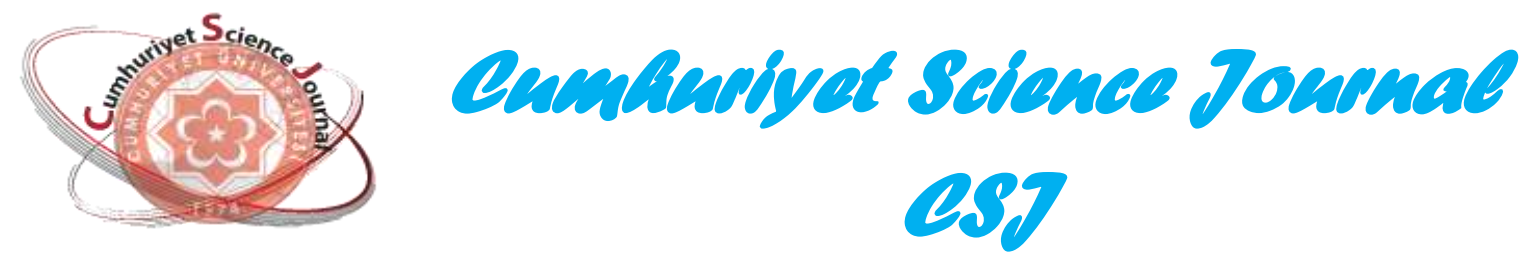

\title{
Influence of Some Cladonia Lichens on Plant Pathogenic Bacteria and Copper Reducing Antioxidant Capacity Activities
}

\author{
Bahar BILGIN SOKMEN ${ }^{1}$, Sinem AYDIN ${ }^{2 *}$, Kadir KINALIOGLU ${ }^{2}$ \\ ${ }^{I}$ Department of Chemistry, Faculty of Science and Arts, Giresun University, 28100, Giresun / TURKEY \\ ${ }^{2}$ Department of Biology, Faculty of Science and Arts, Giresun University, 28100, Giresun / TURKEY
}

Received: 12.05.2017; Accepted: 22.11.2017

http://dx.doi.org/10.17776/csj.358762

\begin{abstract}
Microorganisms such as bacteria and fungi lead many diseases in plants. A great deal of pathogenic microorganisms has gained resistance against frequently utilized antibiotics and synthetic fungicides. Lichens are symbiotic associations between a fungus, an algae or a cyanobacterium. Lichens and their metabolites are demonstrated to be encouraging alternatives to synthetic chemicals. The aim of this study was to reveal the antibacterial effect of ethyl acetate extracts of Cladonia stellaris, Cladonia pyxidata and Cladonia furcata lichen species. Extracts were obtained by Soxhlet extraction. Whereas antibacterial activity was determined by the disc diffusion method, antioxidant activity was determined by copper reducing antioxidant capacity (CUPRAC) method. The best antibacterial activity was found in C. stellaris extract $(25 \mathrm{~mm})$, which was stronger than the positive control antibiotics (ampicillin and tetracycline) against Pseudomonas syringae pv. syringae and Erwinia carotovora subsp. carotovora. The CUPRAC activity was increased in the following order: C. furcata $>$ C. pyxidata $>$ C. stellaris. Further studies are needed on isolation of active constituents from lichen extracts and their biological activity studies are to be worked out.
\end{abstract}

Keywords: Lichen, Antibiotic, Antioxidant activity

\section{Bazı Cladonia Likenlerinin Bitki Patojeni Bakterileri Üzerine Etkileri ve Bakır İndirgeme Antioksidan Kapasitesi Aktiviteleri}

Özet: Bakteri ve mantar gibi mikroorganizmalar bitkilerde pek çok hastalığa yol açmaktadır. Patojenik mikroorganizmaların çoğu sıklıkla kullanılan antibiyotiklere ve sentetik fungisitlere direnç kazanmıştır. Likenler bir mantar, bir alg veya bir siyanobakteriyum arasındaki simbiyotik birliklerdir. Likenler ve metabolitlerinin sentetik kimyasallara karşı umut vaat edici alternatifler olabilecekleri gösterilmiştir. Bu çalışmanın amacı Cladonia stellaris, Cladonia pyxidata ve Cladonia furcata likenlerinin etil asetat ekstraktlarının antibakteriyal etkisini ortaya koymaktır. Ekstraktlar sokslet ekstraksiyonu ile elde edilmiştir. Antibakteriyal aktivite disk difüzyon metodu ile belirlenirken, antioksidan aktivite bakır indirgeme antioksidan kapasitesi (CUPRAC) metodu ile belirlenmiştir. En iyi antibakteriyal aktivite C. stellaris ekstraktında ( $25 \mathrm{~mm})$ pozitif kontrol antibiyotiklerinden (ampisilin ve tetrasiklin) daha fazla olarak Pseudomonas syringae pv. syringae ve Erwinia carotovora subsp. carotovora'ya karşı bulunmuştur. CUPRAC aktivitesi $C$. furcata $>C$. pyxidata $>$ C. stellaris şeklinde artmaktadır. Liken ekstraktlarından aktif bileşenlerin izolasyonu ve bu bileşiklerin biyolojik aktivitelerinin belirlenmesinde daha ileri çalışmalar gerekmektedir.

Anahtar Kelimeler: Liken, Antibiyotik, Antioksidan aktivite

* Corresponding author. Email address: sinem.aydin@giresun.edu.tr

http://dergipark.gov.tr/csj @2016 Faculty of Science, Cumhuriyet University 


\section{INTRODUCTION}

Plants are subject to diseases by bacteria, fungi and viruses that exist in their surroundings and in soil. Plant diseases gave rise to substantial loss of crop yield [1]. For example, Clavibacter michiganensis subsp michiganensis cause bacterial cancer of tomato [2]. Pseudomonas syringae pv. syringae cause bacterial cancer in cherry, apricot, peach and plum trees [3]. Moreover, Erwinia carotovora subsp. carotovora infects plants by bacterial soft rot, leaf chlorosis and necrosis [4]. Early blight created by Alternaria solani is the most widespread and devastating disease of tomato, which leads substantial decrease in the quantity and quality of tomato [5].

Xanthomonas vesicatoria cause bacterial spot; Clavibacter michiganensis leads bacterial cancer, Pseudomonas corrugate cause bacterial pith necrosis, Ralstonia solanacearum cause bacterial built and Agrobacterium tumefasensis cause crown gall disease [6].

Nowadays quick and efficient controlling of plant diseases which cause microbial contaminations in some agricultural commodities is mostly accomplished by utilize of synthetic pesticides. On the other hand, the continuous and random enforcement of these chemical pesticides has lead health threats in animals and humans due to their toxicity. In recent years, many synthetic pesticides have been banned in worldwide because of their undesired properties such as high toxicity and long degradation duration. In developing countries, they are still being utilized in spite of their detrimental impacts. Many pathogenic bacteria and insect pests have gained resistance against chemical pesticides. This situation severely obstructs the controlling of diseases of crops and agricultural products [7].

The utilize of pesticides for crop protection increased based on a growing world population and the requirement for more food supplies. On the other hand, bioaccumulation through the food chain can create a risk to mammals because pesticides have many negative effects. Some pesticides sprayed on crops will remain in farmland, but some of them will mix the surrounding soil, water, and air. pesticides might remain in the environment for many years and may be transported over a long distance [8]. Keeping in mind hazardous effects of synthetic pesticides, there is an urgent demand to find an alternative for management of pathogenic microorganisms. Plant derived secondary metabolites, which have defensive function may be utilized for the conrolling of diseases. Disease controlling through plant extracts has been recorded by different researchers in different crops [9].

Lichens are symbiotic associations between an algae, a fungi or cyanobacterium. Lichens have been used in different industries such as parfume, pharmacy and dye. Moreover, they used as traditional medicines in different parts of world [10]. Moreover, there are various studies about usage of lichens as antimicrobial agent against phytopathogenic microorganism [11, 13].

Free radicals are formed by physiological processes in the body or external sources like smoking and excessive sunlight exposure. Physiological processes are not detrimental, but the body couldn't cope with excessive free radical formation so this leads to immune system and other illnesses [14]. Free radicals also leads oxidative deterioration. Oxidative deterioration decrease the nutritional quality and safety of foods because of creation of secondary and toxic compounds. Antioxidant is a method which also increasing the shelf life of foods [15].

One of the antioxidant activity method is copper reducing antioxidant capacity. The CUPRAC assay was utilized to investigate the capacity of the antioxidants in the extracts to reduce cupric copper to the cuprous form. CUPRAC test has many advantages such as applicability to both hydrophilic and lipophilic antioxidants; the redox reaction giving rise to a colored chelate of $\mathrm{Cu}$ (I)neocuproine is relatively insensitive to factors, i.e., air, sunlight, and $\mathrm{pH}[16]$. 
The current study aims the antibacterial activity of three Cladonia lichen species namely Cladona stellaris, Cladonia pyxidata and Cladonia furcata and copper reducing antioxidant capacity activity.

\section{MATERIALS AND METHODS}

\subsection{Collecting the Lichen Samples and Extraction}

The samples were collected from the following localities in 2014:

- C. stellaris: Trabzon, Arakl1, near Uzuntarla, 2390 m, on soil.

- C. pyxidata: Trabzon, Arakl1, Kızılkaya plateau, 2170 m, on soil.

Table 1. Traditional usage
C. furcata: Giresun, south slopes of Giresun castle, 130 $\mathrm{m}$, on soil.

These samples were dried at room temperature and authenticated by utilizing Smith et al. [17]. Voucher specimens $C$. furcata (Herbarium no: 6393), C. pyxidata (Herbarium no: 6394) and $C$. stellaris (Herbarium no: 6395) are kept at the herbarium of the Biology Department, Faculty of Science and Arts, Giresun University, Giresun, Turkey.

Biological activities of the studied lichen species were given in Table 1.

\begin{tabular}{ll}
\hline Lichen & Traditional Usage \\
\hline Cladonia stellaris & Treating intestinal parasites [18], Antimicrobial [19] \\
Cladonia pyxidata & Astringent and Febrifugal, Antibiotic, Lists in the Pharmacopoeia Universalis of 1846 [20]. \\
Cladonia furcata & Polysaccharides isolated from C. furcata were shown to induce cell death (apoptosis) in \\
& human leukemia K562 cells [20]. Furthermore, C. furcata polysaccharides decreased the \\
& activity of telomerase [21]. \\
\hline
\end{tabular}

Lichens dried on laboratory and then they were grounded into powder. $30 \mathrm{~g}$ lichen was extracted with $300 \mathrm{ml}$ ethanol, ethyl acetate with a Soxhlet extractor. The extracts were filtered using Whatman No. 1 filter paper and then the solvents were evaporated in a vacuum at $40^{\circ} \mathrm{C}$ using a rotary evaporator. Each extract stored at $4^{\circ} \mathrm{C}$ before analysis [22].

\subsection{Bacterial Strains}

Ten bacterial strains were used to assess the antibacterial effect of the extracts. Pseudomonas vesicularis, Clavibacter michiganensis subsp. michiganensis, Pseudomonas cichorii, Pseudomonas savastoni pv. fraxinus, Xanthomonas axanopodis pv. malvecearum, Chrysobacterium indolthecium, Pseudomonas syringae pv. syringae, Erwinia carotovora subsp. carotovora, Xanthomonas phaseoli and Xanthomonas hortanum pv. pelargonii isolates were obtained from Assoc. Prof. Dr. Recep KOTAN, Faculty of Agriculture, Plant Production

\section{Department, Atatürk University.}

\subsection{Determination of Antibacterial Impact}

The antibacterial activity of plant extracts was performed by using disc diffusion method [23]. Each lichen extract was dissolved in dimethyl sulphoxide (DMSO) at $20 \mathrm{mg} / \mathrm{ml}$ concentration. Dissolved extracts were sterilized by using $0.45 \mu \mathrm{m}$ pore sized filter. Inhibition zones of the lichens were compared with standard antibiotics (ampicillin and tetracycline). The sterilized nutrient agar medium was poured into petri dishes and was allowed to solidify. The turbidity of bacterial suspensions was compared with 0.5 McFarland standard, then, the bacterial suspension inoculated into Mueller Hinton agar plates. Discs were put ( $5 \mathrm{~mm}$ diameter) on the agar surface and discs were filled with $25 \mu \mathrm{L} C$. stellaris extract, 25 $\mu \mathrm{l}$ C. pyxidata extract, $25 \mu \mathrm{l}$ C. furcata extract and $25 \mu \mathrm{l}$ DMSO, separetaly. The inoculated plates were left in the refrigerator for one hour, then plates were incubated at $37^{\circ} \mathrm{C}$ overnight [24]. Clear 
inhibition zones around the discs indicated the presence of antibacterial activity. Diameter of inhibition zones was measured in millimeters.

2.4. CUPRAC Assay: CUPRAC test was employed by the method of Özyürek et al. (2009). $0.5 \mathrm{ml}$ extract (prepared in 50-200 $\mu \mathrm{g} / \mathrm{ml}$ ), $1.0 \mathrm{ml}$ $\mathrm{CuCl}_{2}$ solution $\left(1 \times 10^{-2}\right), 1.0 \mathrm{ml}$ neocuproine solution $\left(7.5 \times 10^{-3} \mathrm{M}\right)$ and $1.0 \mathrm{ml}$ ammonium acetate buffer (1.0 M, pH: 7.0) were mixed in a test tube. Then, the tube was vortexed and stored in a dark place for $30 \mathrm{~min}$. absorbance was read at 450 $\mathrm{nm}$. Butylated hydroxytoluene (BHT) was used as standard antioxidant agent [25].

\section{RESULTS}

The effects on the bacteria of the lichens are summarized in Table 2 and Inhibition zones created by the tested lichen extracts were shown in Fig 1. The data obtained from the study revealed that the lichen extracts exhibited antibacterial activities at variable degrees against tested bacteria, with inhibition zones varying from 6-25 $\mathrm{mm}$. P. vesicularis and C. michiganensis subsp. michiganensis were resistant to all the lichen extracts investigated in this work. The best antibacterial activity was found in C. stellaris extract $(25 \mathrm{~mm})$, which was stronger than the positive control antibiotics (ampicillin and tetracycline) against $P$. syringae pv. syringae and Erwinia carotovora subsp. carotovora.

C. furcata extract showed generally little activity (7-10 mm) only against tested bacteria. Bacterial growth was generally resistant to the reference antibiotic ampicillin. DMSO was used as negative control and any inhibition zone didn't create around DMSO discs.

Table 2. Inhibition zones of the tested lichens ( $\mathrm{mm})$.

\begin{tabular}{lcccccc}
\hline Bacteria & C. stellaris & C. pyxidata & C. furcata & DMSO & Amp. & Tetra \\
\hline$P$. vesicularis & NA & NA & NA & NA & NA & 20 \\
\hline$P$. cichorii & 19 & 11 & 10 & NA & NA & 22 \\
\hline$P$. savastonoi pv. fraxinus & 17 & 14 & 8 & NA & NA & 19 \\
\hline C. indolthecium & 14 & 10 & 7 & NA & NA & NA \\
\hline$X$. phaseoli & 6 & NA & NA & NA & NA & 23 \\
\hline$X$. axanopodis pv. vesicotoria & 12 & NA & NA & NA & NA & 32 \\
\hline C. michiganensis subsp. michiganensis & NA & NA & NA & NA & NA & NA \\
\hline$X$. axanopodis pv. malvearrum & 18 & 21 & 9 & NA & 6 & 19 \\
\hline$P$. syringae pv. syringae & 25 & 15 & NA & NA & NA & 20 \\
\hline$E$. carotovora subsp. carotovora & 25 & 19 & 10 & NA & 6 & 20 \\
\hline$X$. hortanum pelargonii & 10 & NA & NA & NA & NA & 13 \\
\hline NA. No Activity
\end{tabular}

NA: No Activity; Amp: Ampicillin; Tetra: Tetracycline

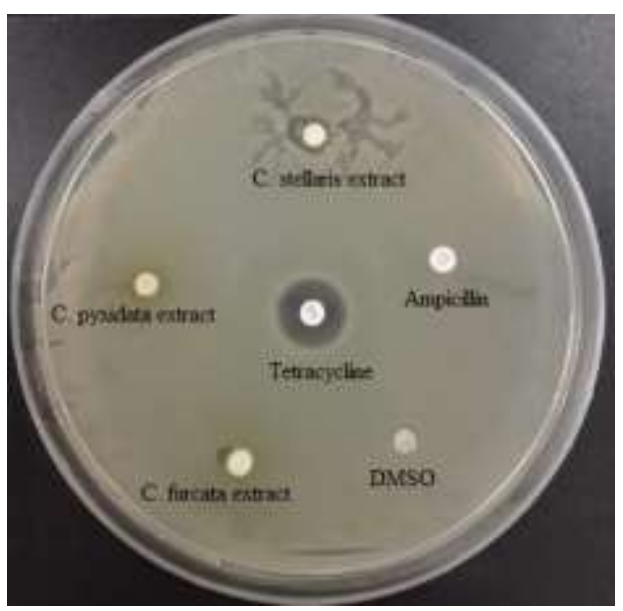

(a)

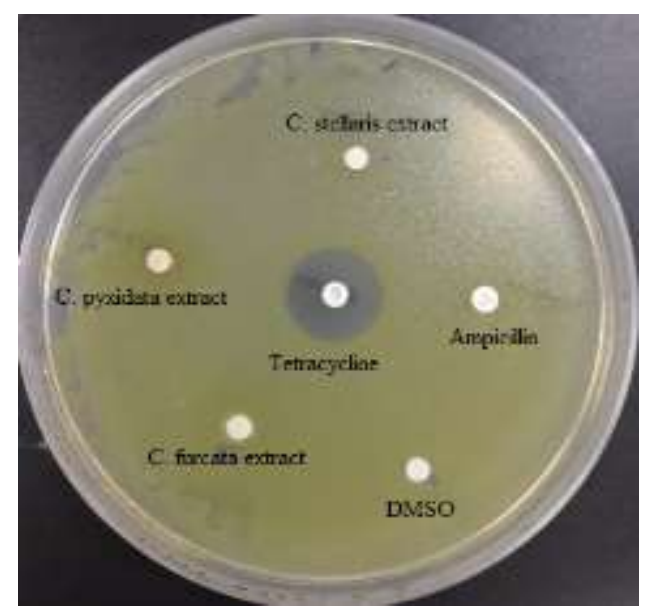

(b) 


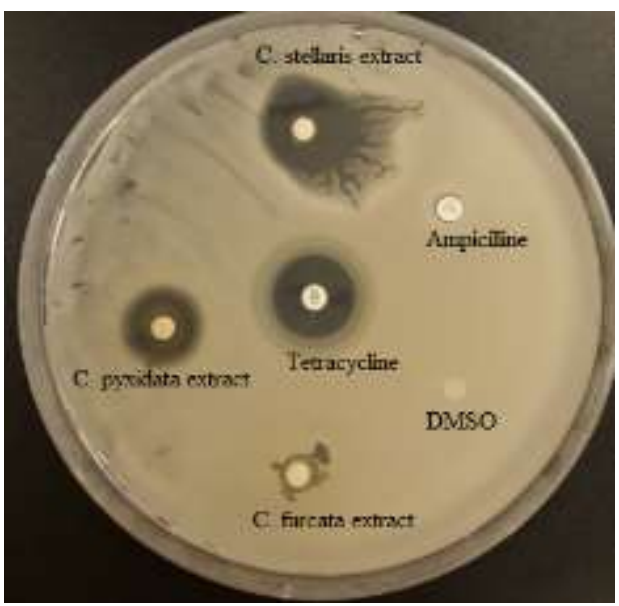

(c)

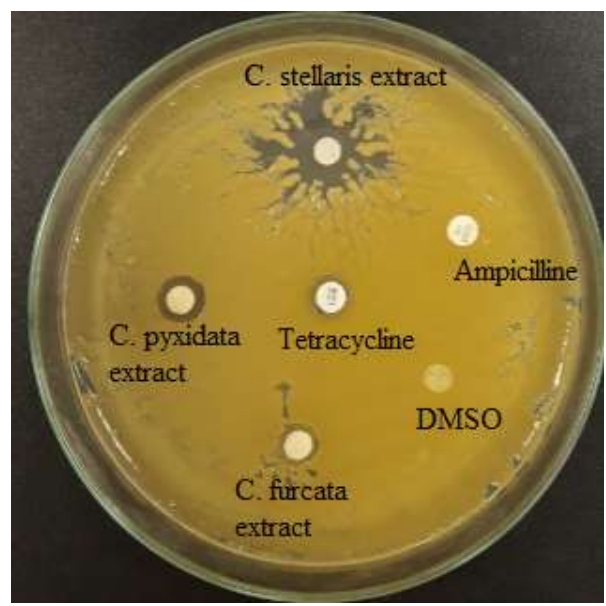

(d)

Figure 1. Antibacterial activity of the lichen extracts against Xanthomonas hortanum pelargonii (a), Xanthomonas phaseoli (b), Erwinia carotovora subsp. carotovora (c) and Chrysobacterium indolthecium (d).

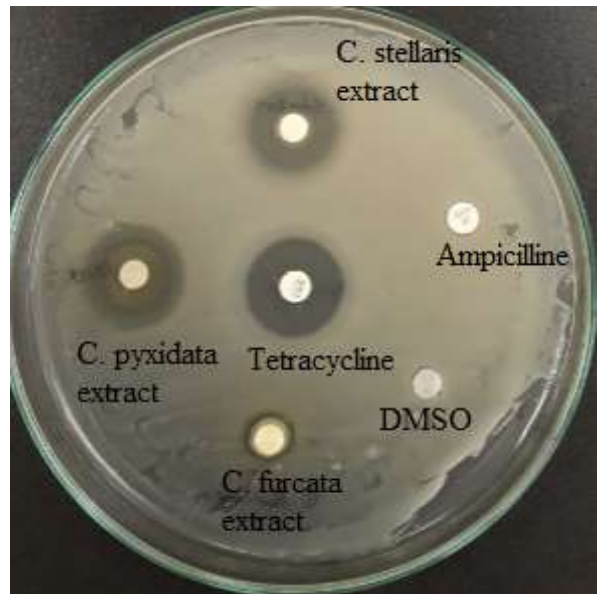

(e)

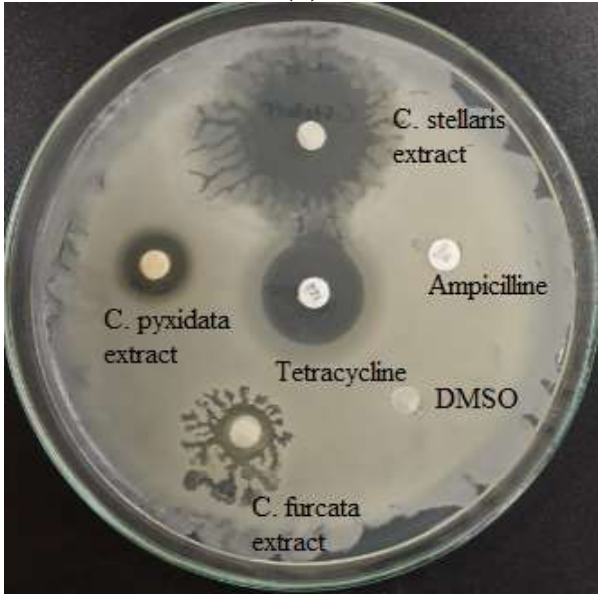

(g)

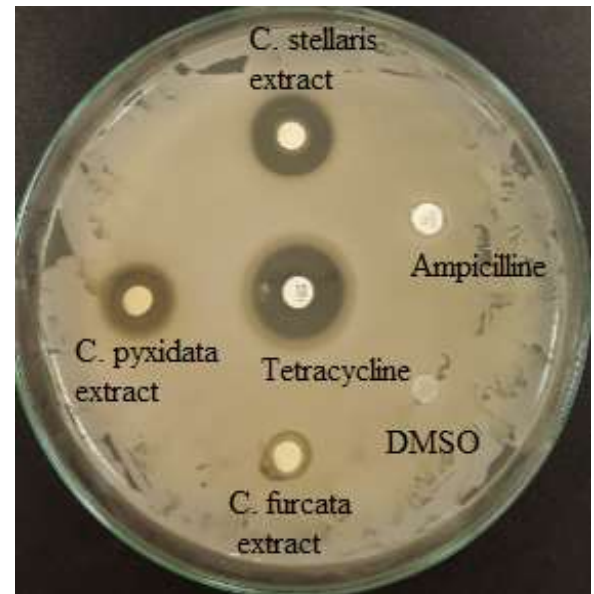

(f)

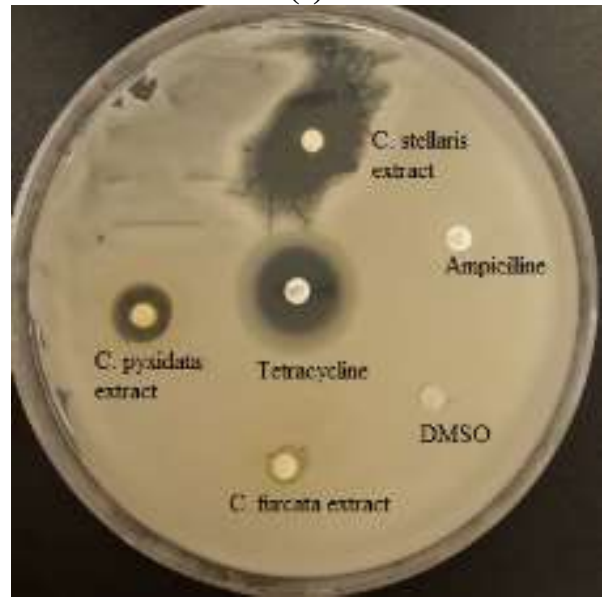

(h)

Figure 2. Antibacterial activity of the lichen extracts against Xanthomonas axanopodis pv. malvearrum (e) and Pseudomonas savastonoi pv. fraxinus (f), Pseudomonas cichorii ( $g$ ) and Pseudomonas syringae pv. syringae (h).

CUPRAC activities of the extracts and BHT presented Table 3. All the lichens indicated high CUPRAC activity. The activity was increased in the following order: C. furcata $>$ C. pyxidata $>C$. stellaris. CUPRAC activity was increased when the concentration of the lichens increased. 
Table 3. CUPRAC values of lichen extracts and BHT.

\begin{tabular}{ccc}
\hline Lichen & $\begin{array}{c}\text { Concentration } \\
(\boldsymbol{\mu g} / \mathbf{m l})\end{array}$ & Absorbance* \\
\hline C. & 50 & $0.138 \pm 0.018$ \\
stellaris & 100 & $0.209 \pm 0.012$ \\
& 150 & $0.304 \pm 0.021$ \\
& 200 & $0.364 \pm 0.009$ \\
\hline C. & 50 & $0.177 \pm 0.008$ \\
pyxidata & 100 & $0.233 \pm 0.011$ \\
& 150 & $0.377 \pm 0.009$ \\
C. furcata & 200 & $0.437 \pm 0.019$ \\
\hline & 50 & $0.240 \pm 0.043$ \\
& 100 & $0.280 \pm 0.015$ \\
& 150 & $0.374 \pm 0.071$ \\
& 200 & $0.529 \pm 0.021$ \\
\hline BHT & 50 & $0.501 \pm 0.007$ \\
& 100 & $0.595 \pm 0.032$ \\
& 150 & $0.718 \pm 0.060$ \\
\hline *Mean \pm SD & 200 & $0.866 \pm 0.013$ \\
\hline
\end{tabular}

\section{DISCUSSION}

Pharmaceutical industry needs new discoveries and improvement of brand medicinally active molecules [26].

Plant derived drugs and herbal medicines have been utilized since prehistoric times to cure human illnesses. Lichens synthesize various metabolites which called lichen substances. These substances are amino acid derivatives, aromatic compounds, dibenzofurans, depsides and depsidones. Lichen metabolites have significant biological activity like antiviral, antipyretic, enzyme inhibitory, antioxidant, allergenic and antibiotic. [27]. Moreover, lichens are noteworthy plant resources and are employed as food, spice, dyes and perfume industry and decoration [26].

There are different studies about antimicrobial activity of C. stellaris, C. pyxidata and C. furcata. For example, Paudel et al. (2014) investigated antimicrobial activity of $C$. stellaris and it was found that extract was inhibited Staphylococcus aureus but inactive against Escherichia coli and Candida albicans [28]. Kosanic et al. (2014) investigated inhibitory activity of acetone extracts of $C$. furcata and $C$. pyxidata lichens against Bacillus mycoides, Bacillus subtilis, Escherichia coli, Klebsiella pneumoniae, Staphylococcus aureus, Aspergillus flavus, Aspergillus fumigatus, Candida albicans, Penicillium purpurescens and Penicillium verrucosum [29].

Rankovic et al. (2009) revealed that acetone and methanol extracts of $C$. furcata inhibited Bacillus mycoides, Enterobacter aerogenes, Bacillus subtilis, Klebsiella pneumoniae and Staphylococcus aureus but aqueous extract of $C$. furcata was inactive against test microorganisms [30].

Rankovic et al. (2011) also studied antimicrobial activity of acetone extract of $C$. furcata against Bacillus mycoides, Bacillus subtilis, Staphylococcus aureus, Enterobacter cloaceae, Escherichia coli, Klebsiella pneumoniae, Aspergillus flavus, Aspergillus fumigatus, Botrytis cinerea, Candida albicans, Fusarium oxysporum, Mucor mucedo, Paecilomyces variotii Penicillium purpurescens, Penicillium verrucosum and Trichoderma harsianum [31].

Jeon et al. (2009) studied antifungal activities of $C$. pyxidata against Colletotrichum acutatum, Colletotrichum coccodes and Colletotrichum gloesporioides which cause hot pepper anthracnose [32].

Studies also carried out about antimicrobial activity of different lichen species. Sesal et al. (2016) investigated methanol and chloroform extracts of Ramalina canariensis, Ramalina chondrina, Ramalina fastigiata and Ramalina fraxinea against Pseudomonas aeruginosa, Escherichia coli, Enterococcus faecalis, Staphylococcus aureus and Candida albicans. It was found that extracts of the lichens demonstrated inhibitory activity against the tested microorganisms in different levels [33].

Sarı̈zlü et al. (2016) evaluated acetone, methanol and chloroform extracts of Bryoria capillaris and its barbatolic acid against Bacillus cereus, Bacillus subtilis, Escherichia coli, Enterococcus faecalis, Enterobacter aerogenes, Klebsiella pneumoniae, Listeria monocytogenes, Micrococcus luteus, 
Mycobacterium tuberculosis, Pseudomonas aeruginosa, Proteus vulgaris, Staphylococcus aureus, Salmonella typhimurium, Yersinia enterocolitica, Candida parapsilosis, Candida albicans, Candida globrata, Candida krusei, Aspergillus niger, Aspergillus flavus, Aspergillus parasiticus, Fusarium moniliforme, Aspergillus fumigatus, Alternaria brassicola, Sclerotium rolfsii, Fusarium solani and Rhizopus sp. [34].

Uçarkuş et al. (2017) investigated antibacterial activity of acetone extract of Parmelia saxatilis and Parmelia sulcata lichens against Escherichia coli [35].

In the light of these antimicrobial activity studies, researchers tried to explore biopesticide property of different lichen species and many researchs have been carried out.

To the best of our knowledge, there is no study about the antibacterial activity of lichen against phytopathogenic bacteria in the literature. However, there are a great deal of studies about antifungal activity of lichens against phytopathogenic fungi. For example, Shivanna and Garampolli (2015) worked out fungistatic property of ethyl acetate and methanol extracts of Flavoparmelia caperata, Parmotrema austrosinensis, Parmotrema grayanum, Parmotrema reticulatum, Parmotrema tinctorum, Physcia aipolia, Roccella montagnei and Teloschistes flavicans against Fusarium solani causing rhizome rot disease [36].

Antifungal activity of some lichens against phytopathogenic fungi Macrophomina phaseolina was revealed by Rashmi and Rajkumar [37]. Kekuda et al. (2014) demonstrated the biocontrol ability of Parmotrema tinctorum, Parmotrema grayanum and Parmotrema prasorediosum lichens against Colletotrichum capsici isolated from anthracnose of chilli [13].

The antimicrobial activity of plant extracts depends on the species of plant, the amount which used in the test, locations where the plant collected, the type of solvent and the type of tested microorganism [38]
This study is the first report about antimicrobial activity of $C$. stellaris, $C$. pyxidata and $C$. furcata lichens against phytopathogenic bacteria.

Halliwell \& Gutteridge describe antioxidants as "a substance that, when exist at low concentrations compared with those of an oxidizable substrate, crucially retards or prevents oxidation of that substrate" [39]. Lichens compounds also possess powerful antioxidant property and have high ability to scavenge toxic free radicals because of their phenolic metabolites such as usnic acid and anthraquinone [26].

Different lichen species was screened in regard of antioxidant activity. Aoussar et al. (2017) was stated dichloromethane, acetone and methanol extracts of Evernia prunastri and Pseudevernia furfuracea have antioxidant activity [40].

Ismail et al. (2014) revealed antioxidant activity of methanol extract of Caloplaca trachyphlla and Xanthoparmalia scabrosa lichens [41].

Rankovic et al. (2014) surveyed antioxidant activity of methanol extract of Stereocaulon paschale lichen. It was demonstrated that $S$. paschale has antioxidant power [42].

Kosanic et al. (2014) worked DPPH radical scavenging activity, reducing power, superoxide anion radical scavenging, total phenolic content and total flavonoid content of C. pyxidata [29]. DPPH radical scavenging activity of $C$. stellaris was revealed by Paudel et al. [28].

Rankovic et al. (2011) carried a study related with DPPH free radical scavenging activity, superoxide anion radical scavenging activity and reducing power of $C$. furcata lichen [31].

This is the first study about CUPRAC activity of $C$. stellaris, C. pyxidata and C. furcata lichens.

\section{CONCLUSION}

It might be generally concluded that the acquired data remarked the probability of utilizing the tested lichens as a natural antibacterial source against plant pathogenic bacteria and antioxidant source. The lichens may be an actual and a cheaper 
substitute for traditional medicines. Furthermore, the development of natural antimicrobial and antioxidant agents will help to decline the negative effects of synthetic drugs. Fractionation and characterization of these active biocompounds will be the future work to explore.

\section{CONFLICTS OF INTEREST}

The authors stated that did not have conflict of interests.

\section{REFERENCES}

[1]. Al-Askar A.A., Hafez E.E., Kabeil S.A., Meghad A., Bioproduction of silver-nano particles by Fusarium oxysporum and their antimicrobial activity against some plant pathogenic bacteria and fungi. Life Sci $\mathbf{J}$ 2013; 10 (3), 2470-2475.

[2]. Bitki Koruma Rehberi, Available at: https://bitkikorumarehberi.wordpress.com/2 012/08/20/ domateste-bakteriyelkanserclavibacter-michiganensis-subspmichiganensis/ Retrieved May 5, 2017.

[3]. Bitki Sağlığı Danışmanlığı, Available at: http://www.bitkisagligi. net /seftali/ ozellik. asp? patlatin=Pseudomonas $\% 20$ syringae $\% 20$ pv. \%20 syringae Retrieved April 29, 2017.

[4]. Post Harvest Diseases of Chillies, Available at: http://slideplayer.com/slide/6615220/ Retrieved April 25, 2017.

[5]. Joseph A., Ese E.A., Ademiluyi B.O., Aluko P.A., Efficacy of selected plant extracts in the management of tomato early blight disease caused by Alternaria solani. Asian J Plant Pathol 2017; 11: 48-52.

[6]. Valdes R.A., Castillo F.D.H., Cabello J.C.A., Fuentes Y.M.D., Morales G.G., Cantu D.J., Aguilar C.N., Review of antibacterial activity of plant extracts and growth-promoting microorganism (GPM) against phytopathogenic bacterial tomato crop. Eur J Biotechnol Genet Eng 2017; 4 (1): 11-36.

[7]. Satish S., Raveesha K.A., Janardhana G.R., Antibacterial activity of plant extracts on phytopathogenic Xanthomonas campestris pathovars. Let Appl Microbiol 1999; 28 (2): 145-147.

[8]. Pesticides, Environmental Pollution and Health, Available at: https://www.intechopen.com/books/environ mental-health-risk-hazardous-factors-toliving-species /pesticides-environmentalpollution-and-health Retrieved April 13, 2017.

[9]. Naidu K.C., Vadlapaudi V., In vitro bioactivity against important phytopathogens of Rhizophora mucronata (Lam.) and Acanthus iliciformis Linn. Der Pharm Lett 2010; 2 (2): 107-110.

[10]. Rankovic B., Misic M., Sukdolak S., Antimicrobial activity of extracts of the lichens Cladonia furcata, Parmelia caperata, Parmelia pertusa, Hypogymnia physodes and Umbilicaria polyphylla, Biologia 2009; 64 (1), 53-58.

[11]. Rashmi S., Rajkumar, H.G., Evaluation of antifungal activity of lichen extracts against phytopathogenic fungi Macrophomina phaseolina (Tassi) Goid. Int J Curr Res 2015; 7 (7): 17718-17721.

[12]. Babiah P.S., Upreti D.K., John S.A., An in vitro analysis of antifungal potential of lichen species Parmotrema reticulatum against phytopathogenic fungi. Int J Curr Microbiol Appl Sci 2014; 3 (12): 511-518.

[13]. Kekuda P.T.R., Vivek M.N., Kambar Y., Manasa M., Biocontrol potential of Parmotrema species against Colletotrichium capsici isolated from anthracnose of chilli. $\mathbf{J}$ Biol Sci Opin 2014; 2 (2): 166-169.

[14]. Karasakal A., Evaluation of antioxidant activities of Brassica napus's seeds by CUPRAC, ABTS persulphate and DMPD methods. Marmara Pharm J 2015; 19 (2): 153-158.

[15]. Huda-Faujan N., Noriham A., Norrakiah A.S., Babji A.S., Antioxidant activity of plants methanolic extracts containing phenolic compounds. Afr J Biotechnol 2009; 8 (3): 484-489.

[16]. Rico M., Sanchez I., Trujillo C., Perez N., Screening of the antioxidant properties of crude extracts of six selected plant species 
from the Canary Islands (Spain). J Appl Bot Food Qual 2013; 86: 217-220.

[17]. Smith C.W., Aproot A., Coppins B.J., Fletcher A., Gilbert O.L., James P.W., Wolseley P.A. The Lichens of Great Britain and Ireland. British Lichen Society, London.

[18]. Lichens and Wildlife, Available at: http://www.lichen.com/bigpix/Cstellaris.ht ml Retrieved April 25, 2017.

[19]. Star- Tipped Reindeer Lichen, Available at: http://inaturalist.ca/taxa/125632-Cladoniastellaris Retrieved May 5, 2017.

[20]. Ethnolichenology of The World, Available at:

http://web.uvic.ca/ stucraw/part2AM.html Retrieved May 2, 2017.

[21]. Cladonia furcata: Wikis, Available at: http://www.thefullwiki.org/Cladonia_furcat a. Retrieved May 2, 2017

[22]. Kumar S., Dhankhar S., Arya V.P., Yadav S., Yadav J.P., Antimicrobial activity of Salvadora oleoides Decne against some microorganisms. J. Med. Plants Res 2012; 6 (14): 2754-2760.

[23]. Saric C.L., Cabarkapa S.I., Beljkas M.B., Misan C.A., Sakac B.M., Plavsic V.D., Antimicrobial activity of plant extracts from Serbia. Food Process Qual Saf 2009; 1 (2): $1-5$.

[24]. Ababutain I.M., Antimicrobial activity of ethanolic extracts from some medicinal plant. Aust J Basic Appl Sci 2011; 5 (11): 678-683.

[25]. Özyürek M., Bektaşoğlu B., Güçlü K., Apak R., Measurement of xanthine oxidase inhibition activity of phenolics and flavonoids with a modified cupric reducing antioxidant capacity (CUPRAC) method. Anal. Chim. Acta 2009; 636 (1): 42-50.

[26]. Bisht S., Sharma S., Kumar V., Kumar M., Bisht S.S., Nautiyal B.P., Assessment of antimicrobial efficacy of secondary metabolites of lichen species from Uttarakhand temperate Himalayas, India. J Nat Prod 2014; 7: 168-176.

[27]. Dharmadhikari M., Jite P.K., Chettiar S., Antimicrobial activity of extracts of the lichen and its isolated mycobiont
Parmelinella simplicior. Asian J Exp Biol Sci Spl 2010; 54-58.

[28]. Paudel B., Bhattarai H.D., Kim I.C., Lee H., Sofronov R., Ivanova L., Poryadina L., Yim J.H., Estimation of antioxidant, antimicrobial activities and brine shrimp toxicity of plants collected from Oymyakon region of the Republic of Sakha (Yakutia), Russia. Biol Res 2014; 47: 10-16.

[29]. Kosanic M., Rankovic B., Stanojkovic T., Rancic A., Manojlovic N., Cladonia lichens and their major metabolites as possible natural antioxidant, antimicrobial and anticancer agents. LWT-Food Sci Technol 2014; 59: 518-525.

[30]. Rankovic B., Misic M., Sukdolak S., Antimicrobial activity of extracts of the lichens Cladonia furcata, Parmelia caperata, Parmelia pertusa, Hypogymnia physodes and Umbilicaria polyphylla. Biologia 2009; 64 (1): 53-58.

[31]. Rankovic B.R., Kosanic M.M., Stanojkovic T.P., Antioxidant, antimicrobial and anticancer activity of the lichens Cladonia furcata, Lecanora atra and Lecanora muralis. BMC Complement Altern Med 2011; 11: 97-104.

[32]. Jeon H., Lökös L., Han K.S., Ryu J., Kim J.A., Koh Y.J., Hur J., Isolation of lichen forming fungi from Hungarian lichens and their antifungal activity against fungal pathogens of hot pepper anthracnose. Plant Pathol J 2009; 25 (1): 38-46.

[33]. Sesal C., Çobanoğlu G., Karaltı İ., Açıkgöz B., In vitro antimicrobial potential of four Ramalina lichen species from Turkey. Curr Res Environ Appl Mycol 2016; 6(3): 202209.

[34]. Sarıözlü N.Y., Cankılıç M.Y., Candan M., Tay T., Antimicrobial activity of lichen Bryoria capillaris and its compound barbatalic acid. Biomed Res 2016; Special Issue, 419-423.

[35]. Uçarkuş E., Gökalsın B., Yıldırım N., Açıkgöz B., Özyiğitoğlu G., Sesal N.C., Balıkesir bölgesinden toplanan liken örneklerine ait özütlerin Escherichia coli ATCC 25922 üzerindeki antibakteriyel 
etkinlikleri Türk Mikrobiyol Cem Derg 2017; 47 (1):26-32.

[36]. Shivanna R., Garampolli R.H., Evaluation of fungistatic potential of lichen extracts against Fusarium solani (Mart.) Sacc. causing rhizome rot disease in ginger. J Appl Pharm Sci 2015; 5 (10): 62-72.

[37]. Rashmi S., Rajkumar H.G., Evaluation of antifungal activity of lichen extracts against phytopathogenic fungi Macrophomina phaseolina (Tassi) Goid. Int. J. Curr. Res. 2015; 7 (7): 17718-17721.

[38]. Obeidat M., Shatnawi M., Al-Alawi M., AlZubi E., Al-Dmoor H., Al-Qudah M., ElQudah J., Otri I., Antimicrobial activity of crude extracts of some plant leaves. Res J Microbiol 2012; 7 (1): 59-67.

[39]. Djeussi D.E., Noumedem J.A.K., Seukep J.A., Fankam A.G., Voukeng I.K., Tankeo S.B., Nkuete A.H.L., Kuete V., Antibacterial activities of selected edible plants extracts against multidrug-resistant Gram-negative bacteria. BMC Complement Altern Med 2013; 13 (164): 1-8.

[40]. Aoussar N., Manzali R., Nattah I., Rhallabi N., Vasiljevic P., Bouksaim M., Douira A., Manojlovic N., Mellouki F., Chemical composition and antioxidant activity of two lichens species (Pseudevernia furfuracea $\mathrm{L}$ and Evernia prunastri L) collected from Morocco. J Mater Environ Sci 2017; 8(6): 1968-1976.

[41]. Ismail M., Ali S., Abbas H.F., Mahboob T., Ahmed K., Choudhary M.I., Antioxidant potential of various fractions of lichen species of Gilgit-Baltistan, District HunzaNagar. Int J Biosci 2014; 5(9): 346-353.

[42]. Rankovic B., Kosanic M., Stanojkovic T., Stereocaulon paschale lichens as antioxidant, antimicrobial and anticancer agents Farmacia 2014; 62 (2): 306-317. 